\title{
Analysis of peripheral vascular injuries: A social catastrophe
}

\author{
Periferik damar yaralanmaları analizi: Sosyal bir katastrofi
}

\author{
Süleyman Yazıcı, Oğuz Karahan, Orkut Güçlü, Celal Yavuz, Sinan Demirtaş, Ahmet Çalışkan, \\ Orhan Tezcan, Binali Mavitaş
}

\begin{abstract}
Objective: In the current study, peripheral vascular injuries caused from weapons and the associated clinical outcomes were retrospectively investigated.

Methods: Two hundred patients who received a surgical procedure for a vascular injury between January 2009 and December 2011 were included in the study. The patients were evaluated retrospectively; type of injury, localization, characteristics, and type of surgical application were classified.
\end{abstract}

Results: Weapon-related penetrating injuries were classified as gunshot injuries $(n=55,28 \%)$, stab wounds ( $n=$ $143,71 \%)$, and mine injuries $(n=2,1 \%)$. There were 77 interposition applications (71 arterial and 6 venous) with saphene vein grafts, 16 arterial interposition applications with polytetrafluoroethylene grafts, and 11 venous ligations. A total of 170 direct repairs (134 arterial and 36 venous) were performed. Postoperative amputation was required in none of the cases, advanced intensive care unit follow-up was required for four patients (2\%; two cases were referred with hypovolemic shock and two case were referred with asystole), and a postoperative follow-up period for any mortality was not observed.

Conclusion: Some regions contain higher levels of war injuries. Therefore, these regions require specialized intervention centres. A large amount of these injuries are vascular, and surgery and rapid interventions are essential for reducing mortality and morbidity rates. Successful results can be obtained in these cases through the collaboration of various medical disciplines.

Key words: Peripheral vascular injuries, war surgery, collaborative management

\section{ÖZET}

Amaç: Bu çalışmada, silahların neden olduğu vasküler yaralanmalar ve ilgili klinik sonuçları retrospektif olarak araştırıldı.

Yöntemler: Ocak 2009 ile Aralık 2011 yılları arasında vasküler yaralanma nedeniyle cerrahi prosedür uygulanan 200 hasta çalışmaya dahil edildi. Hastalar retrospektif olarak değerlendirilerek; yaralanma tipi, lokalizasyonu, karakteristikleri ve cerrahi uygulama şekli açısından sınıflandırıldı.

Bulgular: Silah ilişkili penetran yaralanmalar ateşli silah yaralanması $(n=55, \% 28)$, kesici delici alet yaralanması $(n=143, \% 71)$ ve mayın yaralanması olarak $(n=2, \% 1)$ sınıflandırıldı. Yetmiş yedi safen ven ile interpozisyon uygulaması (71 arteryal and 6 venöz), 16 polytetrafloroetilen ile arteryal interpozisyon uyuglaması ve 11 ven ligasyonu mevcuttu. Toplam 170 (134 arteryal and 36 venöz) direk onarım uygulandı. Hiçbir olguda ameliyat sonrası amputasyon gerekmezken, 4 (\%2; 2 hasta hipovoloemik şok ve 2 hasta da asistol ile ilgili olarak) hastada yoğun bakım ünitesi takibi gerekti ve ameliyat sonrası izlem süresinde mortalite gözlenmedi.

Sonuç: Bazı bölgeler yüksek düzeyde savaş yaralanmalarına sahiptir. Bu nedenle, bu bölgeler özelleşmiş müdahale merkezlerine intiyaç duyarlar. Bu yaralanmaların çoğu damarsaldır ve cerrahi ve hızlı girişimler mortalite ve morbidite oranlarını düşürmek için esastır. Bu vakalarda birçok medikal disiplinin ortak çalışması ile başarılı sonuçlar elde edilebilir.

Anahtar kelimeler: Periferal vasküler yaralanmalar, savaş cerrahisi, işbirlikçi yönetim 


\section{INTRODUCTION}

Today, trauma is one of the most common causes of mortality and morbidity worldwide. Traffic accidents, home accidents, military- or civilian-sourced weapon and stab injuries, falls, sports injuries, psychological self-mutilation or suicide, and a combination of these events can cause trauma. If all trauma-related injuries were combined, trauma would be the third leading cause of death overall and the leading cause of death in people between the ages of 1 and 44 [1]. Vascular injuries comprise $2 \%$ to $3 \%$ of all traumas and have serious morbidity risks [2]. One of the most comprehensive civilian trauma studies was undertaken by Mattox and colleagues; it went on for 20 years and included nearly 6,000 cardiovascular injuries in 4,459 patients, $90 \%$ of whom suffered from a penetrating trauma and $6,8 \%$ of whom suffered from blunt trauma. A large amount of these traumas was from gunshot wounds [3]. In a similar research study in the United Kingdom, 60\% of injuries were found to be iatrogenic [4].

As can be seen from these studies, the cause of trauma differs depending on socioeconomic, cultural, and geographic factors. And as Sir Wyme Ow reported in 1915 [5], Mesopotamia, which has been the homeland of several civilizations for centuries and therefore the location of countless wars, is an important region in which to conduct multidisciplinary research of peripheral artery injuries.

Unfortunately, complicated political and social events are still taking place today in this region, and peripheral artery injuries are frequent occurrences. The aim of the current study was to evaluate the short-term effects of vascular injuries and to analyse the clinical outcome of these patients. In this article, we share significant results from our analysis in light of this historical experience and the current literature.

\section{METHODS}

Ethical approval was taken from local ethical committee. Our study included a retrospective analysis of patients who were admitted with peripheral vascular injuries to the cardiovascular department between 2009 and 2011. Of the 200 patients studied, $178(89 \%)$ were male and $22(11 \%)$ were female. The mean age was $22.09 \pm 7.37$ (mean \pm standard deviation) with an overall age range of 13 to 78 years. Most of the cases (168 patients, 84\%) were admitted to the hospital within 6 hours of being injured. The remaining 32 patients $(26 \%)$ were admitted to the emergency department more than 6 hours after their injury because they were referred from another centre, were from another region, etc. The distribution of the injuries according to etiological factors is presented in Table 1.

Table 1. Etiological Distribution of Injuries

\begin{tabular}{lcc}
\hline Etiology & Case $(\boldsymbol{n})$ & $\%$ \\
\hline Stab wound & 143 & 71 \\
Gun shot & 55 & 28 \\
Mine & 2 & 1 \\
\hline Total & 200 & 100 \\
\hline
\end{tabular}

Patients with active bleeding, expanding hematoma, distal ischaemia, or palpable thrill or bruit were operated on immediately. Four patients (2\%) received cardiac and other systemic procedures, such as mechanic ventilation support or inotropic supplements, between their time of arrival at the hospital and the onset of their operation (two cases were referred with hypovolemic shock and two case were referred with asystole), and these patients all required intensive care after their operations.

The majority of the patients $(148,74 \%)$ were directly operated on without any additional radiological examination except an emergency vascular Doppler ultrasound. Vascular structures were evaluated with computed tomography (CT) angiography to confirm the injuries in $43(22 \%)$ patients with complex injuries. Other system radiographic examinations were applied in 9 (4\%) patients. The localizations of injuries were presented in the Table 2.

All surgical interventions were performed under general anaesthesia except for the radial and ulnar injuries, which were managed under local anaesthetic. The first aim of the surgeries was to stabilize the hemodynamic parameters of the patients. After this, the treatment strategy was focused on providing blood flow to the distal segments of the injuries. For all of the operations, the proximal and distal segments of the injured artery or vein were found and evaluated for re-emergence. Thrombectomy was performed if a thrombotic segment was 
detected. The patients were given $100 \mathrm{IU} / \mathrm{kg}$ heparin intravenously to control bleeding. Preoperative antibiotics were given, and prophylactic treatments were performed for all patients; in addition, postoperative peripheral vasodilator treatment was performed with a dextran-pentoxifylline (Rheomacrodex $500 \mathrm{cc} /$ Trental 2 x $400 \mathrm{mg}$ ) infusion, and postoperative anticoagulant therapy was given with appropriate low-molecular weight heparin to all individuals.

Table 2. The Anatomic Locations of Injuries

\begin{tabular}{lcc}
\hline Affected Extremity & Injured Vessel & $n(\%)$ \\
\hline & Axillar artery & $4(2)$ \\
& Brachial artery & $35(16)$ \\
& Ulnar artery & $34(15)$ \\
& Radial artery & $48(22)$ \\
Upper limb & Combined radial and & $11(5)$ \\
& ulnar artery injury & $132(60)$ \\
& Total & $34(15)$ \\
\hline & Additional major venous injury & $12(5)$ \\
& Common femoral artery & $20(9)$ \\
& Superficial femoral artery & $7(3)$ \\
& Profunda femoris artery & $25(12)$ \\
& Popliteal artery & $12(5)$ \\
Lower limb & Anterior tibial artery & $8(4)$ \\
& Posterior tibial artery & $5(2)$ \\
& Combined trifurcation injury & $18(8)$ \\
\hline & Total & $221(100)$ \\
\hline & Additional major venous injury &
\end{tabular}

\section{RESULTS}

A total of 200 individuals were operated upon (221 arterial and 52 venous injuries). A total of 170 linear vascular injuries were detected (134 arterial and 36 venous), and direct repairs were performed (endto-end anastomosis was performed for 122 injuries with total cut and 58 lateral suturations were performed for the subtotal or partial vessel injuries). Polytetrafluoroethylene (PTFE) grafts were used for interposition of the 16 arterial injuries that could not be repaired directly due to distance or other rea- sons such as fragmented injuries. Venous ligation was performed for 11 venous injuries due to severe bleeding and multifragmented injuries. Saphenous vein interposition was performed for 77 vascular injuries to provide sufficient blood flow (71 arterial and 6 venous), including major main branch injuries. The distribution of performed procedures is given in Table 3.

Table 3. Distribution of performed procedures

\begin{tabular}{lcc}
\hline Procedure & $\begin{array}{c}n \text { (Arterial- } \\
\text { Venous) }\end{array}$ & $\begin{array}{c}\% \text { (Arterial- } \\
\text { Venous) }\end{array}$ \\
\hline End-to-end anastomosis & $122(110-12)$ & $44(40-4)$ \\
Lateral suturation & $58(34-24)$ & $21(12-9)$ \\
*PTFE graft interposition & $16(16-0)$ & $6(6-0)$ \\
Saphenous vein graft & $77(71-6)$ & $28(26-2)$ \\
interposition & $11(0-11)$ & $1(0-1)$ \\
Venous ligation & $273(221-52)$ & $100(81-19)$ \\
\hline Total &
\end{tabular}

*Note: PTFE = polytetrafluoroethylene.

Wound debridement was performed for dirty and necrotic wounds. Intraoperatively detected additional nerve, tendon, or muscle injuries were treated collaboratively with other clinics such as plastic surgery or orthopaedic surgery. Fasciotomy was performed for six patients with vascular injuries due to compartment syndrome (3\%); four of the six patients requiring a fasciotomy had popliteal injuries, and two injuries were detected at the trifurcation level. No amputations or mortality were observed in the postoperative period. All the patients were followed up for a minimum of 6 months.

\section{DISCUSSION}

Vascular trauma compromises $2 \%$ to $3 \%$ of all trauma [2], which differs according to geographic, economic, and sociocultural factors. In the United States, gunshot injuries are most frequent, while iatrogenic trauma is the most frequent in England $[3,4]$. There are some studies that show that penetrating vascular trauma comprises $50 \%$ to $70 \%$ of all vascular trauma in Turkey [6]. The results of our study agree with the previous research, which found that vascular injuries are frequent in males as well as children and young adults due to increased physical 
activity [6]. In our study, 178 of the patients were male $(89 \%)$ and the median age was $22.09 \pm 7.37$.

For vascular trauma, timely transfer and rapid intervention is important for clinical outcome. Delays in care often result in the loss of limbs or even life. The primary goal in the management of vascular trauma is homeostasis. Staunching the bleeding with a compress, bandage, or tourniquet and preparing the patient for transfer prevents many complications due to bleeding, such as needing a blood transfusion or even going into hypovolemic shock [7]. Applying pressure to the wounded area decreases the amount of bleeding [8].

Penetrating injuries are the most common type of vascular injuries; however, blunt trauma has also been frequently reported. The injuries in our study included 55 gunshot injuries (28\%), $143 \mathrm{stab}$ wounds $(71 \%)$, and 2 mine injuries (1\%). In these cases, decisions regarding surgical exploration and repair were entirely clinical and were based on distal ischaemia, pulsatile bleeding, expanding hematoma, and palpable thrill or bruit. Indeed, a number of trials have established the primacy of clinical examination over diagnostic arteriography in the diagnosis of vascular injuries from both penetrating and blunt trauma in acute situations $[9,10]$. We think that in such situations, diagnostic arteriography only causes further delay without adding much to the eventual management decision. Ramanathan et al. suggest that there is often arteriography vessel injury in situations where there are multiple external injuries [11]. Mortality and morbidity risks from blunt trauma are higher than those from penetrating vessel injuries, but they are more difficult to diagnose. For this reason, some suggest using angiography for treating blunt trauma [12]. We also recommend angiography for multiple external injuries and blunt trauma but think that direct exploration is best for patients with serious bleeding. For the most relevant imaging test, we prefer CT angiography because of its non-invasiveness, its easy application, and its speed.

The most common cause of morbidity in these patients is associated metabolic disorders due to ischemia or blood depletion, motor deficits due to tissue loss, and damage that affects the skeletal system by orthopaedic events and amputations. Amputation for patients with nonserious tissue loss is usually caused by inadequate or delayed revascularization $[13,14]$. Amputation rates after revascularization in the literature are $1.5 \%$ [15]. At our centre, revascularisation of these traumas has been performed successfully.

In our patients, many injuries were seen in the upper extremities due to mutual fights and similar causes. In the literature, the incidence of upper extremity injuries is $31 \%$ [16], which was similar to what we saw in this study. In reported studies, 74\% of cases were treated with primer repairing [17]. In our series, 138 patients had upper extremity vessel injuries $(69 \%)$, while 62 patients had lower extremity vessel injuries (31\%). Of these, 170 injuries $(85 \%)$ were treated by primer repairing, 77 injuries $(38 \%)$ were treated by saphenous vein interposition, and 16 injuries ( $8 \%$ ) led to PTFE graft interposition [18]. Primary repair is more suitable for fine-cutting knife injuries. We think that the high rate of primary repairs in our study is reasonable because of the frequency of stab injuries.

Continuity of distal flow in such cases is not always possible due to environment tissue edema and compartment syndrome. In cases with a prolonged ischemia time (more than 4 to 6 hours), extensive or big vein ligation, or tissue swelling, we prefer to perform a fasciotomy [19]. In such cases, it is often necessary to avoid loss of a limb. In our study, six patients received a fasciotomy.

Regarding complications, four patients $(2 \%)$ required follow-up in intensive care due to the metabolic and hemodynamic effects of hypovolemia and metabolic effects. In the literature, the common complications of vascular injury are bleeding and wound infection [16]. Of our six patients who suffered from wound infections, all received fasciotomies $(3 \%)$.

In these cases, clinical outcome was determined by timely diagnosis, early and appropriate intervention, and surgical experimentation. In the literature, mortality rates range from $1.5 \%$ to $20 \%$ [20]. We did not experience mortality in any of our patients and have contributed these health quality data to a collaborative study and to the cumulative experience of our clinic.

To sum up, some regions have higher levels of specific life-threatening disorders that require 
specific intervention, such as weapon injuries. Collaborative management for all levels from appropriate transfer to final intervention is as important as expert application for successful clinical outcomes.

\section{REFERENCES}

1. National Center for Injury Control and Prevention, Centers for Disease Control and Prevention. Web-based injury statistics query and reporting system, http://www.cdc.gov/injury/wisqars/index.html, Accessed December 3, 2013.

2. Austin OM, Redmond HP, Burke PE, et al. Vascular trauma A review. J Am Coll Surg 1995;181:91-108.

3. Mattox KL, Feliciano DV, Burch J, et al. Five thousand seven hundred sixty cardiovascular injuries in 4459 patients. Epidemiologic evolution 1958 to 1987. Ann Surg. 1989;209:698-705; discussion 706-707.

4. Golledge J, Scriven MW, Fligelstone LJ, Lane IF. Vascular trauma in civilian practice. Ann R Coll Surg Engl 1995;77:417-420.

5. Wyme OW, Richardson DT, Dodson GE. Cases of gunshot wounds of Mesopotamia. Br Med J 1916;2;789-794

6. Tünerir B, Beşoğul Y, Yavuz T, et al. Periferik arteriyel yaralanmalar ve tedavi sonuçları. Turkish J Thorac Cardiovasc Surg 1998;6:151-154.

7. Bridges E, Biever K. Advancing critical care: Joint combat casualty research team and joint theater trauma system. AACN Adv Crit Care. 2010;21:260-76.

8. Thorey F, Stukenborg-Colsman C, Windhagen H, Wirth CJ. The effect of tourniquet release timing on perioperative blood loss in simultaneous bilateral cemented total knee arthroplasty: a prospective randomized study.Technol Health Care. 2008;16:85-92.

9. Dennis JW, Frykberg ER, Veldenz HC, et al. Validation of nonoperative management of occult vascular injuries and accuracy of physical examination alone in penetrating extremity trauma: 5- to 10-year follow-up. J Trauma 1998;44:243-252.
10. Gillespie DL, Woodson J, Kaufman J, et al. Role of arteriography for blunt or penetrating injuries in proximity to major vascular structures: An evolution in management. Ann Vasc Surg 1993;7:145-149.

11. Ramanathan A, Perera DS, Sheriffdeen AH. Emergency femoral arteriography in lower limb vascular trauma. Ceylon Med J 1995;40:105-106.

12. Rozycki G, Tremblay LN, Feliciano DV, McClelland WB. Blunt vascular trauma in the extremity: Diagnosis, management, and outcome. J Trauma. 2003;55:814-824.

13. Ben-Menachem Y. Vascular injuries of the extremities: Hazards of unnecessary delays in diagnosis. Orthopedics. 1986;9:333-338

14. Menzoian JO, Doyle JE, Cantelmo NL, et al. A comprehensive approach to extremity vascular trauma. Arch Surg 1985; 120:801-805.

15. Morales-Uribe CH, Sanabria-Quiroga AE, Sierra-Jones JM. Vascular trauma in Colombia: Experience of a level I trauma center in Medellín. Surg Clin North Am 2002;82:195210.

16. Menakuru SR, Behera A, Jindal R, et al. Extremity vascular trauma in civilian population: A seven-year review from North India. Injury 2005;36:400-406.

17. Burma O, Uysal A, Özsin KK, et al. Periferik damar yaralanmalarında cerrahi deneyimimiz: 175 olgunun değerlendirilmesi. Turkish J Thorac Cardiovasc Surg 2005; 13:252-254

18. Giannoukas AD. Lower limb revascularization with infragenicular bypass using PTFE graft and the distal vein patch technique: Does it confer any advantage over the distal vein cuff techniques? Eur J Vasc Endovasc Surg 2012;44:183184.

19. Taylor RM, Sullivan MP, Mehta S. Acute compartment syndrome: Obtaining diagnosis, providing treatment, and minimizing medicolegal risk. Curr Rev Musculoskelet Med 2012;5:206-213.

20. Galindo RM, Workman CR. Vascular trauma at a military level II trauma center. Curr Surg 2000;57:615-618. 